\title{
Influence of lubricant oil residual fraction on recycled high density polyethylene properties and plastic packaging reverse logistics proposal
}

\author{
Harley Moraes Martins ${ }^{1}$, Juacyara Carbonelli Campos², Maria José de Oliveira Cavalcanti Guimarães* \\ and Ana Lúcia Nazareth da Silva ${ }^{3}$
}

\author{
1 Instituto Federal do Rio de Janeiro - IFRJ, Arraial do Cabo, RJ, Brazil \\ ${ }^{2}$ Departamento de Processos Orgânicos, Escola de Química, Universidade Federal do Rio de Janeiro - UFRJ, \\ Rio de Janeiro, RJ, Brazil \\ 3Instituto de Macromoléculas Professora Eloisa Mano - IMA, Universidade Federal do Rio de Janeiro - UFRJ, \\ Rio de Janeiro, RJ, Brazil \\ *mjg@eq.ufrj.br
}

\begin{abstract}
To recycle post-consumer HDPE contaminated with waste lubricating oils, companies include prior washing and drying in the process. This consumes large amounts of water and energy, generates significant effluent requiring treatment. This study assesses lubricating oil influence on HDPE properties to evaluate the feasibility of its direct mechanical recycling without washing. The current lubricating oil packaging reverse logistics in Rio de Janeiro municipality is also analyzed. HDPE bottle samples were processed with seven oil contents ranging from 1.6-29.4 (wt\%). The results indicated the possibility to reprocess the polymer with oily residue not exceeding $3.2 \%$. At higher levels, the external oil lubricating action affects the plastic matrix processing in the extruder and injection, and the recycled material has a burnt oil odor and free oil on the surface. Small residual oil amounts retain the plastic properties comparable to the washed recycled polymer and exhibited benefits associated with the oil plasticizer action. However, oil presence above $7.7 \%$ significantly changes the properties and reduces the elasticity and flexural modulus and the plastic matrix crystallinity.
\end{abstract}

Keywords: HDPE, lubricant oils, properties, reverse logistics.

\section{Introduction}

Plastic materials are presented as the ideal solution for diverse industry segments. The possibilities related to easy molding and handling, durability, low weight, among other characteristics, have consecrated their replacement of other materials. HDPE is a type of plastic present in almost all economic sectors ${ }^{[1]}$, but it is precisely the packaging sector that has highlighted its large capacity to adapt to different types of use $\mathrm{e}^{[2]}$.

The packaging industry is almost completely dominated by this material type. As in the food industry, cosmetics, soft drinks and many others, the producers of lubricating oil producers also have opted for polymeric materials. In Brazil, about $2 \%$ of plastic container sold products are lubricating oils $^{[3]}$. In this case, the thermoplastic body of the bottle is high density polyethylene - HDPE.

Lubricating oils pose an environmental contamination risk and classified as hazardous waste, according to the Brazilian standard NBR 10004/04 ${ }^{[4]}$. The base oil and its additives cause impacts by various pathways: soil, water bodies and air. Lei and $\mathrm{Wu}^{[5]}$ stated that a gallon of oil has the potential to contaminate up to one million gallons of drinking water.

Similar to oil, post-consumer automotive lubricant packaging poses an environmental contamination risk, because significant amounts of oil and additives remain in their interior ${ }^{[2,6]}$. Furthermore, the residual lubricant is hard to remove in the package washing process commonly used in Brazil[ ${ }^{[7]}$ magnifying the logistic difficulties and economic viability. The oil and its additives impose a toxicity characteristic to the used packaging and makes it a hazardous waste ${ }^{[8]}$. As such, the measures associated with the contaminated packaging temporary storage, transport and treatment/disposal must conform to strict controls. These appear in the Brazilian environmental laws (federal, state and municipal) and technical standards, such as ABNT NBR 12.235/92, which deals with hazardous waste storage, ABNT NBR 13.221/10 and ABNT NBR 7500/13, which set guidelines for dangerous products and waste transportation, among others.

In the United States, 20 million gallons of waste oil are disposed into the environment each year and such post-consumer plastic packaging with oily residue is not accepted in most of the country's recycling programs ${ }^{[5]}$.

Besides the residual oil important environmental impact in the studied waste classification regarding their potential and logistics system, the oily fraction presence directly affects recycling process operational aspects.

The post-consumed packaging oily presence makes recycling difficult, as it increases the material melt index, and exudes when extruded and after processing. The oily residue affects the recycled artifacts quality causing their deformity. Additionally, processing temperatures above $200{ }^{\circ} \mathrm{C}$ 
can lead to oily residue thermal degradation, conveying a strong burnt oil odor to recycled plastic ${ }^{[9]}$.

Mechanical plastic recycling is deployed on a large scale in Brazil. Packs with oily residue make mechanical recycling more difficult due to the required decontamination steps ${ }^{[5]}$. The conventional cleaning processes include significant water and energy consumption reducing the feasibility of lubricant bottle recycling ${ }^{[10]}$. Therefore, an environmentally and economically feasible oily residue cleaning method is a challenge.

Martins studied the influence of variables such as temperature and bottle position in the HDPE post-consumer lubricant packaging decontamination process by gravitational flow. This focused on the oil collector apparatus structural characteristics and proposed practices to maximize oily waste removal and minimize energy consumption ${ }^{[1]}$.

The technical literature presents various cleaning techniques with aqueous and non-aqueous solvents as well with supercritical fluids, as a package pre-recycle treatment step. However, all techniques are considered expensive, and generate additional waste, preventing reverse logistics of such wastes ${ }^{[5]}$.

This study aims to simplify the automotive lubricant plastic packaging conventional mechanical recycling process by excluding the associated decontamination steps (washing, drying and effluent treatment). The study evaluates HDPE packaging mechanical and thermal properties having been reprocessed with different lubricating oil amounts to establish the limits for direct recycling (without washing). Furthermore, the study also shows the feasibility process for an efficient reverse logistics.

\section{Experimental}

\subsection{HDPE post-consumer bottle processing}

Cleaned and dried lubricating oil bottles were collected from gas stations and then fragmented in a mill, Primotécnica model Knives Mill LP 1003 5HP. 600g of fragmented bottles were blended with known amounts of semisynthetic BR LUBRAX TECHNO lubricating oil (SAE 15W / 40 Flash Point $236{ }^{\circ} \mathrm{C}$ Viscosity index 133) (Table 1).

It is important to emphasize that samples prepared with post-consumer HDPE packaging with different lubricating oil content were representative of results obtained in field research made in 56 gas stations in Rio de Janeiro State Municipality ${ }^{[1]]}$. The values of $1.6 \%, 2.4 \%$ and $3.2 \%$

Table 1. Recycled HDPE/ lubricating oil compositions.

\begin{tabular}{ccc}
\hline Composition & Oil mass $(\mathbf{g})$ & Oil Content $(\mathbf{w t} \%)$ \\
\hline H0* & 0 & 0 \\
H1 & 10 & 1.6 \\
H2 & 15 & 2.4 \\
H3 & 20 & 3.2 \\
H4 & 50 & 7.7 \\
H5 & 100 & 14.3 \\
H6 & 200 & 25.0 \\
H7 & 250 & 29.4 \\
\hline
\end{tabular}

\footnotetext{
* Virgin lubricating oil bottle from COSAN supplier.
}

simulate residual oil supply drainages of $90 \%, 92 \%$ and $95 \%$, respectively. Values of $7.7 \%$ and $14.3 \%$ correspond respectively to minimum and average oil remaining values after drainage found in the field research. Contents of $25 \%$ and $29.4 \%$ correspond to residue supply, according to the literature ${ }^{[5]}$ and residue supply average value according to field research in 56 gas stations.

The compositions were processed in a twin-screw co-rotating extruder (TeckTril, model DCT-20) with $20 \mathrm{~mm}$ diameter and a 36 length to diameter (L/D ratio). The temperature profile was $90^{\circ} \mathrm{C} / 140^{\circ} \mathrm{C} / 160^{\circ} \mathrm{C} / 160^{\circ} \mathrm{C} / 170^{\circ} \mathrm{C} / 170^{\circ} \mathrm{C}$ $/ 180{ }^{\circ} \mathrm{C} / 190{ }^{\circ} \mathrm{C} / 200{ }^{\circ} \mathrm{C} / 210^{\circ} \mathrm{C}$. The sample feed rate in the extruder was 30rpm and the rotational screw speed was $200 \mathrm{rpm}$. The extruded filaments were immediately quenched in water at the die exit and later pelletized in a granulator and then dried in the oven at $60^{\circ} \mathrm{C}$. Injected samples were obtained with a linear screw temperature profile between $170{ }^{\circ} \mathrm{C}$ and $210{ }^{\circ} \mathrm{C}$ from the rear to the injection nozzle with a mold temperature of $30^{\circ} \mathrm{C}$. The injection and back pressures were 1400 bar and 450 bar, respectively, and the injection speed was $26 \mathrm{~cm}^{3} / \mathrm{s}$. An Arburg 270S machine produced Type I samples, according to ASTM D638.

The compositions were characterized regarding the melt flow index (ASTM D1238-13) in a Dynisco Instruments model LMI 4000 , at $190{ }^{\circ} \mathrm{C} / 2,16 \mathrm{~kg}$. The mechanical properties (tensile: ASTM D638-10, flexural: ASTM D790-10, procedure A) were determined in an EMIC Universal Testing machine with speeds of $25 \mathrm{~mm} / \mathrm{min}$ (tensile) and $14 \mathrm{~mm} / \mathrm{min}$ (flexural).

The impact tests, Izod method with notch were conducted according to ASTM D256-10 in CEAST equipment with a 2J pendulum. The differential scanning calorimetric (DSC) analyses were performed on a TA Instruments model Q1000 in the temperature range from $30{ }^{\circ} \mathrm{C}$ to $200{ }^{\circ} \mathrm{C}$, heating rate of $10^{\circ} \mathrm{C} / \mathrm{min}$ under nitrogen flow of $30 \mathrm{ml} / \mathrm{min}$. The crystallinity degree was determined using the enthalpy of fusion of $100 \%$ crystalline HDPE which is $293 \mathrm{~J} / \mathrm{g}$.

\section{Results and Discussion}

The processing was easily performed with oil content compositions up to $2.4 \mathrm{wt} \%$. For higher oil content compositions, the processing became more difficult. This behavior probably occurred due to the friction reduction between the polymer melt and extruder screw.

During the shearing that occurs in processing, the lubricant molecules can migrate, being deposited on the machine walls / screw, with a release film formation between the extruder and the polymeric mass causing the polymer melt slip ${ }^{[12]}$. The same behavior was observed during the injection process in the sample production for characterization tests. Table 2 shows the results of the melt flow index of post-consumer HDPE bottle obtained with different lubricating oil amounts.

A moderate increase in MFI values can be observed compared to a virgin lubricating oil bottle, while in $\mathrm{H} 5$, $\mathrm{H} 6$ and $\mathrm{H} 7$ samples, significant MFI values modification occurred, exceeding a $100 \%$ oil content increase from $14.3 \%$. This fact prevents any potential recycling processes, and directly affects the blow molding process due to the difficulties associated with the "parison" formation. 
The residual oil influence in the recycled HDPE mechanical properties is displayed in Tables 3 and 4 . Based on the samples tensile and flexural tests results, it appears the measured parameter values (elastic and flexural modulus) were progressively reduced as the oil content increased.

This behavior strengthens the interpretation that the lubricating oil has a plasticizing effect on the polymeric matrix. Plasticizers are inserted between the resin macromolecules, favoring slippage and molecular mobility, affecting the mechanical properties ${ }^{[13,14]}$. The plasticizing effect is associated in general with an increase in elongation and a tensile strength and elastic modulus decrease ${ }^{[12]}$.

In tests (tensile and flexural), reductions in modules and the stress yield had greater impact on the oil content samples equal to or higher than $7.7 \%$. The variation has exceeded $76 \%$ in the relation between the Young modulus case for a sample with $29.4 \%$ of oil in comparison with the pure material value.

Considering these results and potential recycled HDPE applications, it is possible to conclude that direct packaging processing with oily residue levels equal to or higher than

Table 2. Melt flow index of recycled post-consumer HDPE / Lubricating oil bottles.

\begin{tabular}{ccc}
\hline Sample & Oil Content (wt.\%) & MFI (g/10min) \\
\hline H0 & 0 & $0.32 \pm 0.08$ \\
H1 & 1.6 & $0.37 \pm 0.08$ \\
H2 & 2.4 & $0.37 \pm 0.02$ \\
H3 & 3.2 & $0.41 \pm 0.06$ \\
H4 & 7.7 & $0.48 \pm 0.09$ \\
H5 & 14.3 & $0.70 \pm 0.05$ \\
H6 & 25.0 & $1.02 \pm 0.09$ \\
H7 & 29.4 & $1.34 \pm 0.18$ \\
\hline
\end{tabular}

the composition represented by $\mathrm{H} 4$ could produce much lower stiffness resins than those commonly used in the market, compromising their marketing and use. Candian studied recycled HDPE use and set the limit of $547 \mathrm{MPa}$ for Young's modulus for structural applications ${ }^{[15]}$. The H0 control sample reached this value as also the compositions $\mathrm{H} 1, \mathrm{H} 2$ and $\mathrm{H} 3$. The other compositions ( $\mathrm{H} 4, \mathrm{H} 5, \mathrm{H} 6$ and $\mathrm{H} 7$ ) presented values below $453 \mathrm{MPa}$ for this parameter.

As previously mentioned, the technical literature has few evaluations of HDPE lubricating oil bottle applicability. Only a patent was found presenting a method to produce composites based on recycling HDPE containers contaminated with lubricating oil (around 3 wt.\%) and cellulosic fibers, to improve its mechanical properties ${ }^{[5]}$.

The impact resistance values of various compositions are shown in Table 5. The experimental data shows the impact resistance slightly increased in the $\mathrm{H} 4$ sample, and was more pronounced in the H5, H6 and $\mathrm{H} 7$ samples. The H6 and $\mathrm{H} 7$ samples did not break under the test conditions.

The impact resistance increase, especially in samples with oil content equal to or higher than the H5 sample, proved the oil plasticizing action, which increases the polymer matrix free volume and leads to an increase in the material's ability to absorb energy ${ }^{[12]}$.

Table 6 displays the results for melting temperature $(\mathrm{Tm})$, enthalpy of fusion $(\Delta \mathrm{Hm})$ and crystallinity degree (Xm) of seven compositions of recycled HDPE / lubricating oil bottles.

When comparing the results for each HPDE sample, a reduction trend can be seen in the Tm value with increasing oil content. The Tm value decrease confirmed the lubricating oil plasticizing effect. The plasticizers increase the macromolecules mobility and reduce their melt temperatures. Thus, the Tm

Table 3. Tensile and impact strength data of recycled HDPE / Lubricating oil bottles.

\begin{tabular}{|c|c|c|c|c|}
\hline Sample & Oil Content (wt\%) & $\begin{array}{c}\text { Young Modulus } \\
\text { (MPa) }\end{array}$ & Stress at Yield (MPa) & Impact Resistence $(\mathrm{J} / \mathrm{m})$ \\
\hline $\mathrm{H} 0$ & 0 & $750( \pm 21.4)$ & $22.0( \pm 0.5)$ & $156.1( \pm 5.4)$ \\
\hline H1 & 1.6 & $671( \pm 6.1)$ & $21.5( \pm 0.2)$ & $155.3( \pm 2.6)$ \\
\hline $\mathrm{H} 2$ & 2.4 & $623( \pm 15.1)$ & $20.9( \pm 0.3)$ & $155.4( \pm 7.4)$ \\
\hline H3 & 3.2 & $599( \pm 26.0)$ & $20.6( \pm 0.3)$ & $155.5( \pm 3.4)$ \\
\hline H4 & 7.7 & $435( \pm 9.3)$ & $18.4( \pm 0.3)$ & $159.1( \pm 4.8)$ \\
\hline H5 & 14.3 & $315( \pm 11.9)$ & $15.8( \pm 0.4)$ & $179.8( \pm 6.2)$ \\
\hline H6 & 25.0 & $200( \pm 10.3)$ & $12.2( \pm 0.3)$ & $\mathrm{ND}^{*}$ \\
\hline $\mathrm{H} 7$ & 29.4 & $178( \pm 10.9)$ & $11.4( \pm 0.4)$ & $\mathrm{ND}^{*}$ \\
\hline
\end{tabular}

* Not determined under the studied test conditions.

Table 4. Parameters of Flexural Tests of Recycled HDPE / Lubricating oil Bottles.

\begin{tabular}{cccc}
\hline Sample & $\begin{array}{c}\text { Oil Content } \\
(\mathbf{w t} \%)\end{array}$ & $\begin{array}{c}\text { Flexural Modulus } \\
\text { (MPa) }\end{array}$ & $\begin{array}{c}\text { Flexural Offset Yield Strength } \\
(\mathbf{M P a})\end{array}$ \\
\hline H0 & 0 & $711.5( \pm 17.6)$ & $22.03( \pm 0.5)$ \\
H1 & 1.6 & $666.0( \pm 13.4)$ & $20.91( \pm 0.8)$ \\
H2 & 2.4 & $661.6( \pm 5.7)$ & $20.51( \pm 0.1)$ \\
H3 & 3.2 & $573.9( \pm 5.2)$ & $18.58( \pm 0.3)$ \\
H4 & 7.7 & $482.3( \pm 16.4)$ & $16.81( \pm 0.6)$ \\
H5 & 14.3 & $416.0( \pm 23.1)$ & $14.48( \pm 0.7)$ \\
H6 & 25.0 & $317.5( \pm 13.5)$ & $10.70( \pm 0.4)$ \\
H7 & 29.4 & $310.7( \pm 4.3)$ & $9.50( \pm 0.3)$ \\
\hline
\end{tabular}


Table 5. Impact resistance data of recycled HDPE / Lubricating oil bottles.

\begin{tabular}{ccc}
\hline Sample & Oil Content (wt \%) & Impact Resistence (J/m) \\
\hline H0 & 0 & $156.1( \pm 5.4)$ \\
H1 & 1.6 & $155.3( \pm 2.6)$ \\
H2 & 2.4 & $155.4( \pm 7.4)$ \\
H3 & 3.2 & $155.5( \pm 3.4)$ \\
H4 & 7.7 & $159.1( \pm 4.8)$ \\
H5 & 14.3 & $179.8( \pm 6.2)$ \\
H6 & 25.0 & ND* \\
H7 & 29.4 & ND* $^{*}$ \\
\hline
\end{tabular}

* Not determined under the studied test conditions.

Table 6. Thermal parameters of recycled HDPE/ Lubricating oil bottles.

\begin{tabular}{ccccc}
\hline Sample & $\begin{array}{c}\text { Oil Content } \\
\text { (wt.\%) }\end{array}$ & $\mathbf{T m}\left({ }^{\circ} \mathbf{C}\right)$ & $\mathbf{\Delta H m}(\mathbf{J} / \mathbf{g})$ & $\mathbf{X m}(\%)$ \\
\hline H0 & 0 & 132.4 & 209.2 & 71.4 \\
H1 & 1.6 & 132.0 & 202.7 & 69.2 \\
H2 & 2.4 & 131.9 & 191.0 & 65.2 \\
H3 & 3.2 & 131.2 & 187.0 & 63.8 \\
H4 & 7.7 & 131.2 & 166.6 & 56.9 \\
H5 & 14.3 & 130.3 & 160.5 & 54.8 \\
H6 & 25.0 & 129.9 & 153.9 & 52.5 \\
H7 & 29.4 & 127.1 & 135.5 & 46.2 \\
\hline
\end{tabular}

value reduction with increased oil content was interpreted as the molecular fraction interference of lubricating oil dispersed in the polymer matrix. The polymer crystalline phase high molecular motion leads to less perfect crystals and a lower crystallinity degree, facilitating an easier melt process ${ }^{[16]}$.

The thermal analysis results, in particular the clear reduction trend in the samples' crystallinity degree with increased oil content, were in accordance with the mechanical tests results. The crystallinity degree reduction causes an elastic modulus decrease and an increase in the material ductility ${ }^{[17]}$.

\subsection{Analysis of current reverse logistics of lubricating oil plastic packaging}

Field research conducted by Martin ${ }^{[11,18]}$ demonstrated that, despite compulsory federal law requirements, the reverse logistics system of automotive lubricant plastic bottles practiced in Rio de Janeiro municipality has significant shortcomings with regard mainly to systematic oily fraction separation from the plastic waste and bottle temporary storage, with direct consequences on the recycling process viability, cost and safe transportation. Field research evidence was collected and proves the only reverse logistics program of this waste type operating in Brazil (Jogue Limpo), presents several operational and logistical problems with direct economic impact and environmental feasibility of the system.

The actual system of logistics considers the lubricating oil bottle transportation without residual oil removal or, in the best case, the post-consumer bottles are taken to an oil collector apparatus, commonly called "dripping", for the gravitational drainage of the waste. The mobile oil collector is a metallic funnel with a small inclination to the horizontal. This structure contributes to poor drainage done at collection points: the bottles remain in the apparatus, often "laying" or very slightly inclined and, consequently, with little oil drainage effect. Furthermore, the lack of definitions - practice currently developed - such as the minimum draining time and the best bottle position during the residual oil gravitational separation process and also the lack of suitable bottle protection media also provoke waste disposal losses.

In the case of post-consumer lubricating oil bottles with oily residue, companies include washing and drying steps which consume large amounts of water and energy, as well as generating significant effluents to be treated. In addition, the excessive residual oil presence hampers the recycling process, causing deformity and a burnt oil odor in the final artifact. These factors have made the activity unfeasible for some recyclers. To recycle such waste and be attractive to entrepreneurs, an effective collection system is necessary, associated with the plastic waste separation from oil contaminant.

Barriers associated with the plastic bottle transport system indicate bottle fragmentation at the lubricating oil point of sale can bring several logistical, environmental and economic benefits associated with the increased material bulk density, for example, a significant collecting trip reduction and smaller material temporary storage area.

Finally, the analyses indicate the urgency to reengineer the reverse logistics system and to suggest the deployment of lubricant packaging decontamination in more appropriate gravitational drainage equipment; fragmentation at the generator point to facilitate material storage and transportation and direct polymer recycling without the washing step.

\section{Conclusions}

Direct mechanical recycling (without washing) of post-consumer lubricating oil bottles is an alternative to increase the feasibility of this waste type reverse logistics. For this technology to be technically and economically feasible, a methodology is necessary to effectively remove the residual oily fraction from the bottles, for the final waste not to compromise the reprocessing, and especially not significantly alter the recycled plastic properties.

Reprocessing HDPE post consumer bottles is feasible with lubricating oil content up to $3.2 \%$. In larger quantities, the lubricant oil external action affects the plastic matrix processing in the extrusion and injection processes, and the recycled material presents a burnt oil odor and free oil on the surface. The HDPE properties with small processed lubricant oil amounts are comparable to the recycled polymer after decontamination by washing, without any prejudice related to the automotive oil plasticizing action. However, the presence of more than $7.7 \%$ of lubricant oil alter the recycled HDPE properties, significantly reducing, for example, the elasticity modulus (flexural and tensile), and the plastic matrix crystallinity degree.

\section{Acknowledgements}

The authors thank FAPERJ (EXTPESQ Project - 2012E-26/111 531/2012) for their financial support. 


\section{References}

1. Associação Brasileira da Indústria Química - COPLAST/ ABIQUIM. (2014, January). São Paulo. Retrieved in 8 January 2014, from http://www.abiquim.org.br/resinastermoplasticas/ default.asp

2. Xavier, L. H., Cardoso, R., Matos, R. M., \& Adissi, P. J. (2006) Legislação ambiental sobre destinação de resíduos sólidos: o caso das embalagens plásticas pós-consumo. In XIII Simpósio de Engenharia de Produção (pp. 1-11). Bauru: UNESP.

3. Programa Jogue Limpo. (2014, March). Retrieved in 3 March 2014, from http://www.programajoguelimpo.com.br/index. php

4. Brasil. Ministério do Meio Ambiente - MMA. (2013). Relatório do Ministério do Meio Ambiente para o Conselho Nacional do Meio Ambiente (CONAMA). Óleo lubrificante usado ou contaminado. Brasília. Retrieved in 7 March 2014, from http://www.mma.gov.br/port/conama/processos/174D441A/ Apres_OLUC_Zilda.pdf

5. Lei, Y., \& Wu, Q. (2009). WO 2009/079273 A2. Composites made of thermoplastic polymers, residual oil, and cellulosic fibers. Retrieved in 23 January 2014, from http://www.google. com/patents/WO2009079273A2?cl=en

6. Brasil. Ministério do Meio Ambiente - MMA. (2011). Plano nacional de resíduos sólidos: versão preliminar. Brasília. Retrieved in 12 February 2014, from http://www.mma.gov.br/ estruturas/253/_publicacao/253_publicacao02022012041757. pdf

7. Kishi, S. A. S. (2008). Conheça a reciclagem de embalagens de óleo lubrificante. Revista das Águas, 2(5). Retrieved in 15 March 2014, from http://midia.pgr.mpf.gov.br/4ccr/sitegtaguas/ sitegtaguas_5/reciclagem.html

8. Federação das Indústrias do Estado de São Paulo - FIESP. (2007). Reciclagem de embalagens plásticas usadas contendo óleo lubrificante. São Paulo: FIESP. Retrieved in 13 November 2013, from http://www.fiesp.com.br/indices-pesquisas-epublicacoes/reciclagem-de-embalagens-plasticas-usadascontendo-oleos-lubrificantes-2007/
9. Pires, A. S. (2004). Reciclagem de frascos plásticos de postos de gasolina. Rio de Janeiro: Núcleo Interdisciplinar de Estudos Ambientais e Desenvolvimento - NIEAD/UFRJ.

10. Martins, H. M. (2005). A destinação final das embalagens de óleo lubrificante: o caso do Programa Jogue Limpo (Master's dissertation). Universidade Estadual do Rio de Janeiro, Rio de Janeiro.

11. Martins, H. M. (2014). Análise do cenário atual e desenvolvimento de metodologia para otimização da logística reversa de embalagens de lubrificantes automotivos pós-consumo (Doctoral thesis). Universidade Federal do Rio de Janeiro, Rio de Janeiro.

12. Rabello, M. S. (2000). Aditivação de polimeros. São Paulo: Artliber.

13. De Paoli, M. A. (2008). Degradação e estabilização de polímeros. São Paulo: Artliber.

14. Parente, R. A., \& Pinheiro, L. M. (2008). Plásticos reciclados para elementos estruturais. Cadernos de Engenharia de Estruturas, 10(47), 75-95. Retrieved in 20 April 2014, from http://www. set.eesc.usp.br/cadernos/nova_versao/pdf/cee47_75.pdf

15. Canadian, L. M. (2007). Estudo do polietileno de alta densidade reciclado para uso em elementos estruturais (Master's dissertation). Universidade de São Paulo, São Carlos.

16. Santos, A. S. F., Freire, F. H. O., Costa, B. L. N., \& Manrich, S. (2012). Sacolas plásticas: destinações sustentáveis e alternativas de substituição. Polímeros: Ciência e Tecnologia, 22(3), 228 237. http://dx.doi.org/10.1590/S0104-14282012005000036.

17. Pradella, J. G. C., Terence, M. C., Miranda, L. F., \& Pereira, N. C. (2010). Estudo das propriedades mecânicas e térmicas do polímero poli-3-hidroxibutirato (PHB) e de compósitos PHB/pó de madeira. Polímeros: Ciência e Tecnologia, 20(1), 65-71. http://dx.doi.org/10.1590/S0104-14282010005000011.

18. Martins, H. M., Nascentes, A. L., Guimarães, M. J. O. C., \& Campos, J. C. (2015). Management of lube oil container: a review. Revista Teccen, 6(1), 13-19. Retrieved in 20 April 2015, from http://www.uss.br/pages/revistas/revistateccen/V6N12015/ pdf/002-Gerenciamento_de_embalagens_de_lubrificantes.pdf

Received: Sept. 19, 2014

Revised: May 12, 2015

Accepted: June 19, 2015 